\title{
Failure and Collapse of Building Structures in the Cities of Yaoundé and Douala, Cameroon from 2010 to 2014
}

\author{
Jean Claude Tchamba ${ }^{1} \&$ Théodore Gautier L. J. Bikoko ${ }^{2}$ \\ ${ }^{1}$ Civil Engineering Laboratory, ENSET, University of Douala, P.O. Box: 1872, Douala, Cameroon \\ ${ }^{2}$ School of Civil and Environmental Engineering, University of The Witwatersrand, Johannesburg, South Africa \\ Correspondence: Théodore Gautier L. J. Bikoko, School of Civil and Environmental Engineering, University of \\ the Witwatersrand, Johannesburg, South Africa. Tel: 27-792-787-723. E-mail: lejeunegautier@rocketmail.com
}

Received: October 10, 2015 Accepted: November 13, 2015 Online Published: December 20, 2015

doi:10.5539/mas.v10n1p23 URL: http://dx.doi.org/10.5539/mas.v10n1p23

\begin{abstract}
The failure and collapse of buildings in most cases result in loss of lives and properties. The incessant collapses of buildings nowadays are so enormous that it has become a serious concern to the professionals in the building industry, clients, governments, and general public. In most cases, the architects and engineers who are directly involved in the construction of such building are held responsible for building collapse. The purpose of this study was to elaborate various cases of building structures collapsed that occurred in Yaoundé and Douala, Cameroon between 2010 and 2014 and to investigate the factors causing such incidents. The methods employed in the collection of data include the administration of questionnaire to professionals in the building industry (professional engineers, architects and construction professionals), site inspections and case studies for the sites. The data collected were analysed using descriptive and analytical statistics. The findings show that the collapse of some buildings in major cities in Cameroon (Yaoundé and Douala) can be attributed to absence of soil investigation and foundation, structural design, detailing, degradation due to environmental factors, use of poor quality materials and concrete processing. In the two case studies considered, the study revealed that the major causes of building failures were excessive loading, structural design, degradation due to environmental factors and other causes. The paper concludes by recommending possible measures to be undertaken by government and other regulatory bodies in the building industry to avert this.
\end{abstract}

Keywords: building collapses, Douala, Yaoundé

\section{Introduction}

The case of building failures and consequent collapse of structures in Cameroon had reached an alarming stage in the past five years. Reporting collapsed buildings in the country was comparable to flood disaster, earthquake and aeroplane clash considering the loss of lives and destruction of properties in different parts of the country.

The need to provide shelter to man and his daily activities has always been an utmost priority. Buildings are constructed to serve as shelter for man and his activities in an environment (Amadi, Eze, Igwe, Okumlola, \& Okoye, 2012; Ayuba, Olagunju, \& Akande, 2012; Oseghale, Ikpo, \& Ajayi, 2015; Tauheed, 2007); therefore they must be properly designed, well planned, constructed and maintained to obtain desired satisfaction from environment. However, recent events in Cameroon in places like Yaoundé and Douala have seen these buildings as a growing cause of death, loss of properties and left many people injured.

The aim of this article is to elaborate various cases that occurred in Yaoundé and Douala, Cameroon between 2010 and 2014 leading to loses of lives and properties. It also mentions the possible causes which could have caused such incidents, along with various suggestions and recommendations to mitigate or ameliorate future buildings collapse in these cities.

\section{Methodology}

To achieve these aims, we demarcated the plots of (500x1000) $\mathrm{m}^{2}$ in certain suburbs (Table 1) of Yaoundé and Douala in which we determined the number of: existing buildings, buildings under construction, buildings showing signs of degradations/defects (cracks in wall, roof defects etc.) and collapsed buildings. Some data collected were obtained through questionnaires combined with direct interviews to professionals involved in the building industry (professional engineers, architects and construction professionals) and interviews to occupied 
respondents. We also interrogated the Cameroonian Civil Engineering Laboratory (LABOGENIE) and the city or town council authorities in order to know the number of buildings legally constructed or having building permits or design approval by local authorities before construction works was undertaken on site in those suburbs. This survey was conducted during the month of March 2014. Quantitative as well as qualitative data were collected. The data collected were analysed using descriptive and analytical statistics.

The suburbs of Yaoundé and Douala subjected to our surveys are shown in Table 1 below.

Table 1. Suburbs of Yaoundé and Douala subjected to our surveys

\begin{tabular}{|c|c|c|c|c|c|c|c|c|c|}
\hline Cities & & & & aoundé & & & Dou & & \\
\hline Suburbs & $\begin{array}{l}\text { Santa } \\
\text { Barbara }\end{array}$ & Odza & Nkolndongo & Emombo & Bonapriso & Akwa & Log-pom & Bépanda & Cité \\
\hline
\end{tabular}

\section{Analysis of Data and Discussion of Results}

Table 2 and 3 present some of the reported cases of building collapse in Yaoundé and Douala respectively from 2010 to 2014, showing the suspected causes and the casualties involved which reveal that 7 people died and 5 others were injured as shown in the two tables.

Table 2. Some reported cases of collapsed buildings (Structures) in Yaoundé (2010-2014)

\begin{tabular}{|c|c|c|c|c|c|}
\hline $\mathbf{S} / \mathbf{N}$ & $\begin{array}{l}\text { Building } \\
\text { location }\end{array}$ & Type of building structure & $\begin{array}{l}\text { Date of } \\
\text { collapse }\end{array}$ & $\begin{array}{l}\text { Suspected causes of } \\
\text { building collapse }\end{array}$ & $\begin{array}{l}\text { Number of lives } \\
\text { lost/Injuries }\end{array}$ \\
\hline 1 & Nkolndongo & $\begin{array}{l}\text { Five-Storey Residential Building } \\
\text { Under Construction }\end{array}$ & $\begin{array}{l}\text { February } \\
26,2010\end{array}$ & $\begin{array}{l}\text { Excessive } \\
\text { Loading, Faulty Design }\end{array}$ & 4 Died \\
\hline 2 & Nkozoa & Ste Thérèse of Jesus Church wall & May 17,2013 & $\begin{array}{l}\text { Faulty Construction, Use of } \\
\text { poor materials }\end{array}$ & 5 Injured \\
\hline 3 & Elig-Essono & $\begin{array}{l}\text { Six-Storey Residential Building } \\
\text { Under Construction }\end{array}$ & $\begin{array}{l}\text { August } \\
18,2010\end{array}$ & $\begin{array}{l}\text { Faulty Design, Faulty } \\
\text { Construction }\end{array}$ & Nil \\
\hline 4 & Simbock & $\begin{array}{l}\text { Three-Storey Residential Building } \\
\text { Under Construction }\end{array}$ & $\begin{array}{l}\text { November } \\
13,2012\end{array}$ & Foundation settlement & Nil \\
\hline 5 & $\begin{array}{l}\text { CNPS- } \\
\text { Yaoundé }\end{array}$ & Office building-Under Construction & $\begin{array}{l}\text { August } \\
27,2012\end{array}$ & Fire disaster & Nil \\
\hline
\end{tabular}

Table 3. Some reported cases of collapsed buildings (Structures) in Douala (2010-2014)

\begin{tabular}{|c|c|c|c|c|c|}
\hline $\mathbf{S} / \mathbf{N}$ & $\begin{array}{l}\text { Building } \\
\text { location }\end{array}$ & Type of building structure & $\begin{array}{l}\text { Date of } \\
\text { collapse }\end{array}$ & $\begin{array}{l}\text { Suspected causes of building } \\
\text { collapse }\end{array}$ & $\begin{array}{l}\text { Number of lives } \\
\text { lost/Injuries }\end{array}$ \\
\hline 1 & Lapeyrere-Akwa & $\begin{array}{l}\text { Four-Storey Residential Building } \\
\text { Under Construction }\end{array}$ & $\begin{array}{l}\text { July } \\
17,2013\end{array}$ & $\begin{array}{l}\text { Faulty Design, Faulty } \\
\text { Construction, Use of poor } \\
\text { materials }\end{array}$ & 2 Died \\
\hline 2 & Ndogbong & $\begin{array}{l}\text { Five-Storey Residential Building } \\
\text { under Construction }\end{array}$ & $\begin{array}{l}\text { May } \\
13,2013\end{array}$ & Foundation settlement & 1 Died \\
\hline 3 & Bépanda & $\begin{array}{l}\text { Multi-Sport Complex Steel Truss } \\
\text { Roof under Construction }\end{array}$ & $\begin{array}{l}\text { January } \\
7,2013\end{array}$ & Faulty Construction & Nil \\
\hline 4 & Akwa-Nord & $\begin{array}{l}\text { Four-Storey Residential Building } \\
\text { under use though under } \\
\text { Construction }\end{array}$ & $\begin{array}{l}\text { May } \\
18,2014\end{array}$ & $\begin{array}{l}\text { Excessive } \\
\text { Loading, Faulty Design, } \\
\text { Degradation due to environment }\end{array}$ & Nil \\
\hline 5 & Kotto Village & $\begin{array}{l}\text { Four-Storey Residential Building } \\
\text { Under Construction }\end{array}$ & $\begin{array}{l}\text { June } \\
15,2012\end{array}$ & Erosion & Nil \\
\hline 6 & Akwa-Sud & $\begin{array}{l}\text { Residential Building Under } \\
\text { Construction }\end{array}$ & $\begin{array}{l}\text { April } \\
11,2011\end{array}$ & $\begin{array}{l}\text { Faulty Construction, Use of } \\
\text { poor materials }\end{array}$ & Nil \\
\hline
\end{tabular}


The results presented in Table 2 and 3 suggest that residential buildings are more prone to collapse in Yaoundé and Douala and there were no reported cases of building collapse in factories or industries. They further show that three, four, five and six- storey buildings, collapse more frequently. This might be due to the fact that buildings above six - storey are not in high demand and are more expensive requiring more resources to build. These buildings (structures) collapsed during construction. Figures 1 and 2 show typical scenes of collapse of structures during construction.

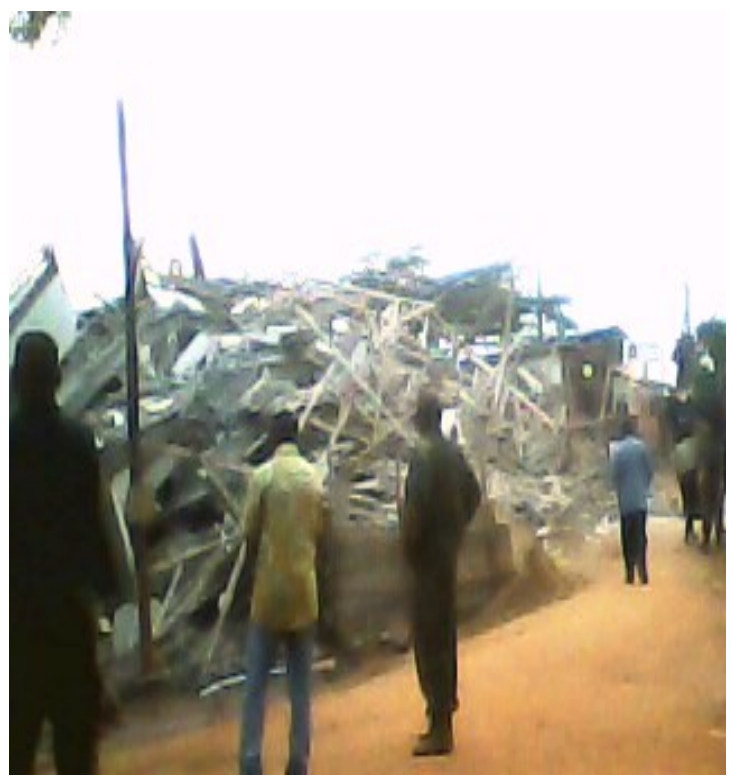

Figure 1. Building collapse at Elig-essono Suburb, Yaoundé

(Source: Journal du Cameroun, 2010).

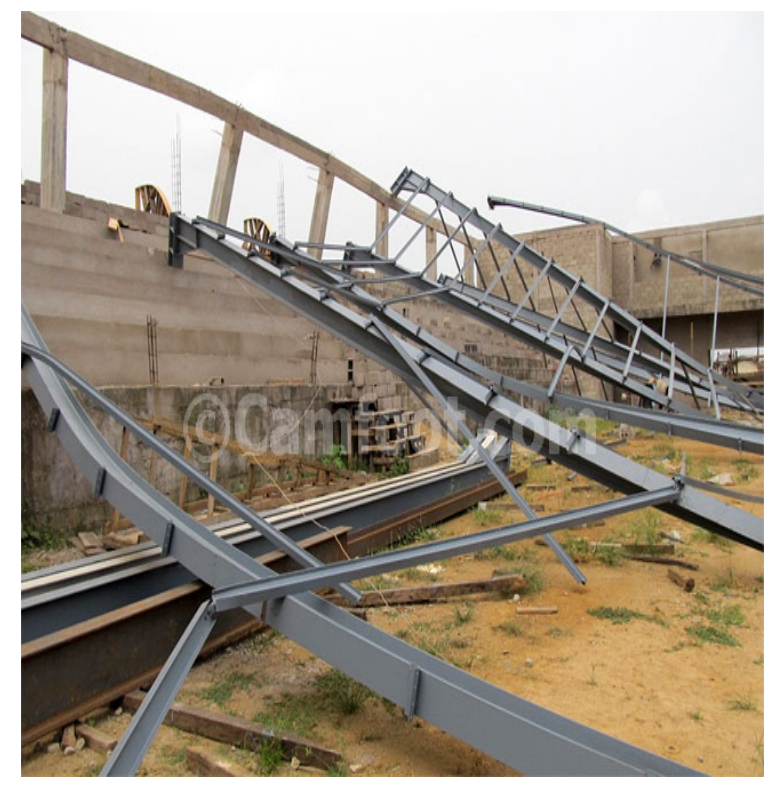

Figure 2. Multi-Sport Complex Steel Truss Roof collapse at Bepanda Suburb, Douala

(Source: Journal le messenger, 2013).

Table 4 presents the data collected in certain sites of Yaoundé and Douala during our investigations. In order to further illuminate the data, figures $3,4,5$ and 6 are presented.

Table 4. Data collected in certain sites of Yaoundé and Douala

\begin{tabular}{|c|c|c|c|c|c|c|c|c|c|}
\hline \multirow{2}{*}{$\begin{array}{l}\text { Cities } \\
\text { Suburbs }\end{array}$} & \multicolumn{4}{|c|}{ Yaoundé } & \multicolumn{5}{|c|}{ Douala } \\
\hline & $\begin{array}{l}\text { Santa } \\
\text { Barbara }\end{array}$ & Odza & $\begin{array}{l}\text { Nkolnd } \\
\text { ongo }\end{array}$ & Emombo & Bonapriso & Akwa & Log-pom & Bépanda & Cité Sic \\
\hline Plots $\left(\mathrm{m}^{2}\right)$ & $\begin{array}{l}500 \\
\times 1000\end{array}$ & $\begin{array}{l}500 \\
\times 1000\end{array}$ & $\begin{array}{l}500 \\
\times 1000\end{array}$ & $\begin{array}{l}500 \\
\times 1000\end{array}$ & $\begin{array}{l}500 \\
\times 1000\end{array}$ & $\begin{array}{l}500 \\
\times 1000\end{array}$ & $\begin{array}{l}500 \\
\times 1000\end{array}$ & $\begin{array}{l}500 \\
\times 1000\end{array}$ & $\begin{array}{l}500 \\
\times 1000\end{array}$ \\
\hline $\begin{array}{l}\text { Number of } \\
\text { buildings }\end{array}$ & 1000 & 950 & 1350 & 1300 & 1000 & 1000 & 800 & 1380 & 1250 \\
\hline $\begin{array}{l}\text { Number of } \\
\text { buildings legally } \\
\text { constructed or } \\
\text { having building } \\
\text { permits }\end{array}$ & 500 & 700 & 120 & 95 & 600 & 300 & 550 & 50 & 180 \\
\hline $\begin{array}{l}\text { Number of } \\
\text { buildings with } \\
\text { signs of } \\
\text { degradations/Defec } \\
\text { ts }\end{array}$ & 25 & 12 & 400 & 650 & 15 & 100 & 15 & 650 & 850 \\
\hline $\begin{array}{l}\text { Number of } \\
\text { building collapses }\end{array}$ & 1 & / & 1 & / & / & 3 & 1 & 1 & / \\
\hline Percentage of & $50 \%$ & $74 \%$ & $9 \%$ & $7.3 \%$ & $60 \%$ & $30 \%$ & $69 \%$ & $3.6 \%$ & $14 \%$ \\
\hline
\end{tabular}




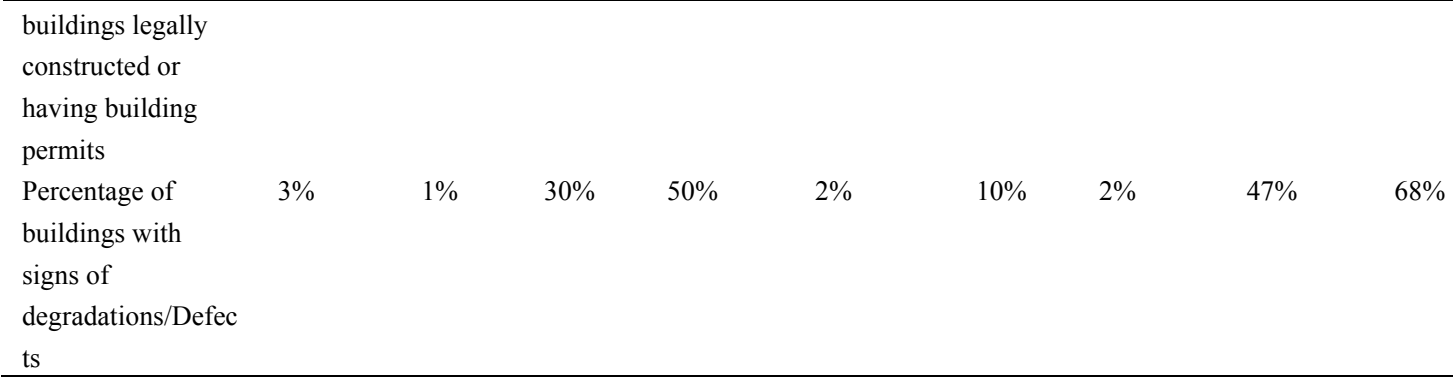

The percentages of buildings legally constructed or having building permits in certain suburbs in the city of Yaoundé are shown in figure 3 below. We observe that the suburb Odza has the highest number of buildings legally constructed or having building permits representing $74 \%$ of the buildings and the suburb Emombo and Nkolndongo the smallest representing $7.3 \%$ and $9 \%$ respectively.

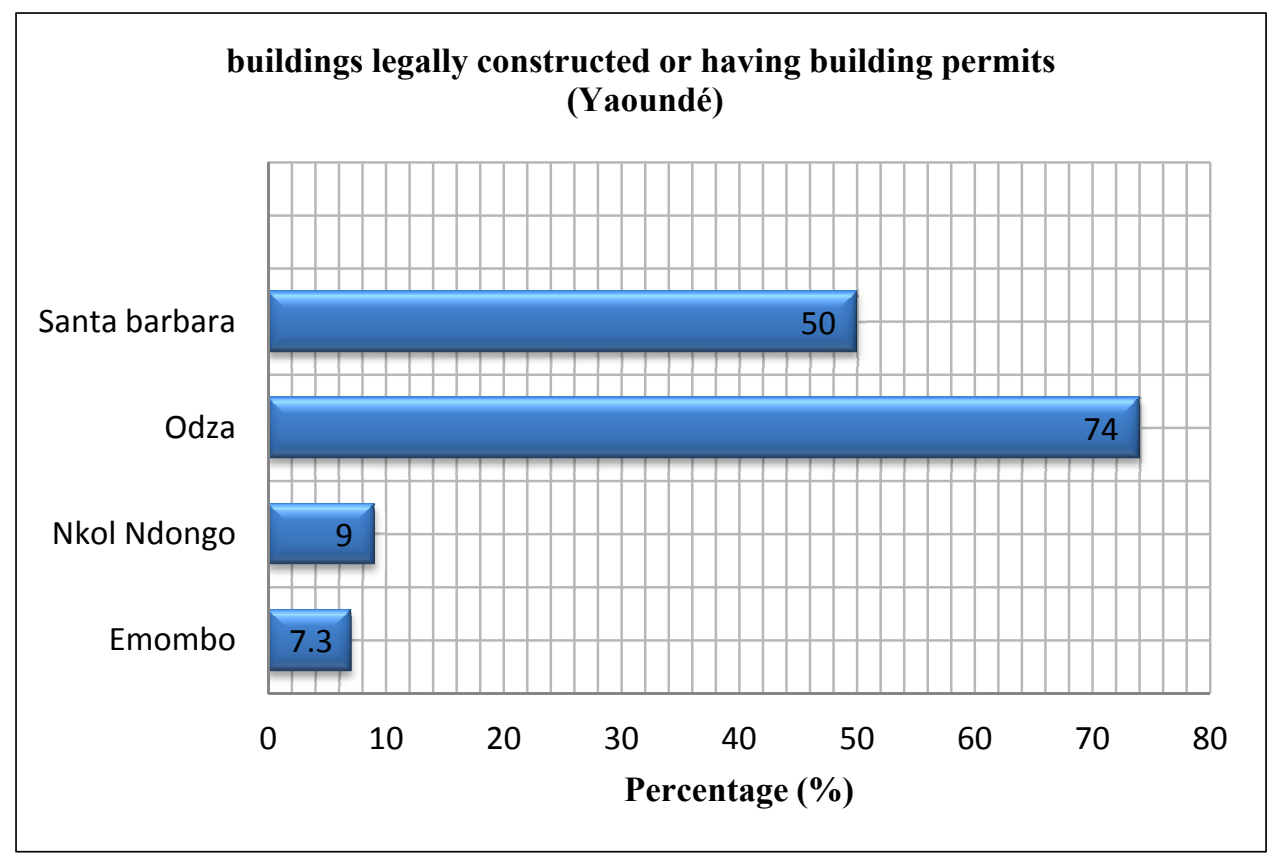

Figure 3. Percentages of buildings legally constructed or having building permits in certain suburbs in the city of Yaoundé

Figure 4 shows the percentages of buildings legally constructed or having building permits in the city of Douala. From this figure, it can be observed that the suburb Log-pom has the highest number of buildings legally constructed or having building permits representing $69 \%$ of the buildings and the suburb Bépanda the smallest representing $4 \%$. 


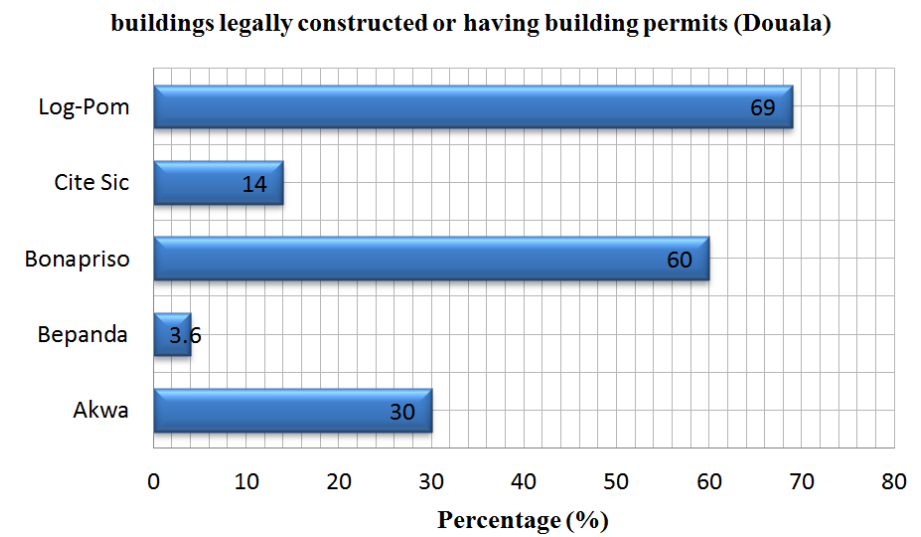

Figure 4. Percentages of buildings legally constructed or having building permits in certain suburbs in the city of Douala

The percentages of buildings in certain suburbs in the city of Yaoundé showing signs of degradations /defects (cracks in walls, roof defects, etc.) can be seen in figure 5 below. We observe that the Emombo suburb has the highest number of buildings with signs of degradations/defects with $50 \%$ of the buildings and the suburb Odza and Santa Barbara the smallest with 1\% and 3\% respectively.

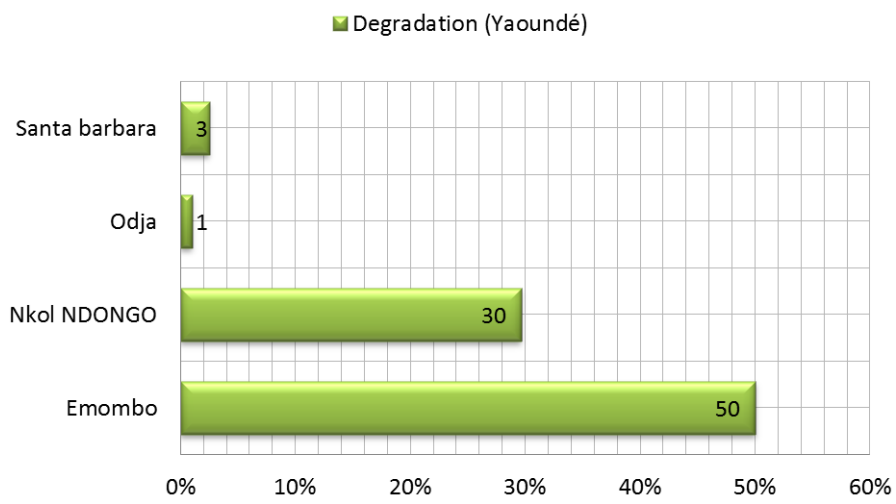

Figure 5. Percentages of buildings in certain suburbs in the city of Yaoundé with signs of degradations/defects

Figure 6 represents the percentages of buildings in certain suburbs in the city of Douala showing signs of degradations/defects (cracks in walls, roof defects, etc.). From this figure, it can be observed that the suburb Cité SIC has the highest number of buildings showing signs of degradations/defects with $68 \%$ of the buildings and the suburb Bonapriso and Log-pom the smallest with $2 \%$ each.

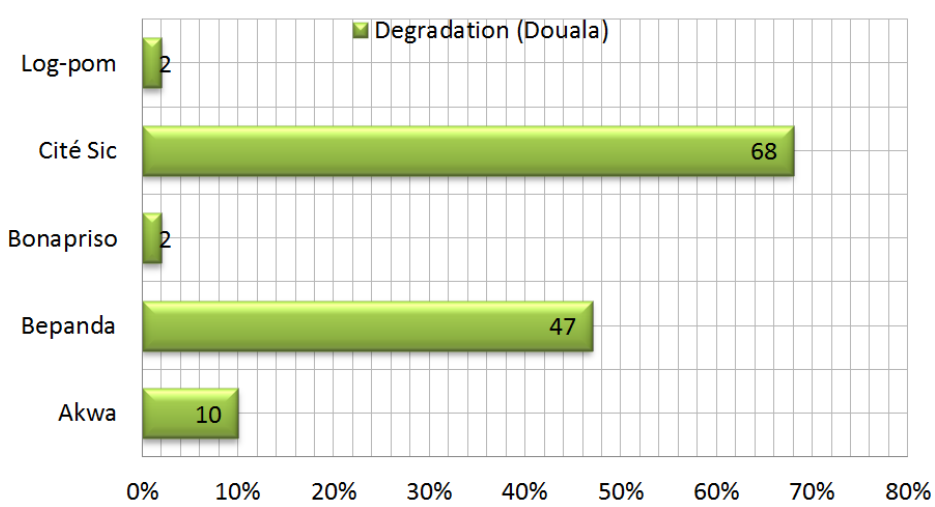

Figure 6. Percentages of buildings in certain suburbs in the city of Douala with signs of degradations/defects 
The percentages of causes of buildings collapse in the cities of Yaoundé and Douala are shown in figure 7 below. Soil investigation and foundation, structural design and detailing form major causes of buildings collapse in the cities of Yaoundé and Douala. The trio had 25\%,18\% and 20\% occurrence respectively. It can be observed also that $17 \%$ of the building collapses in these cities are due to concrete processing.

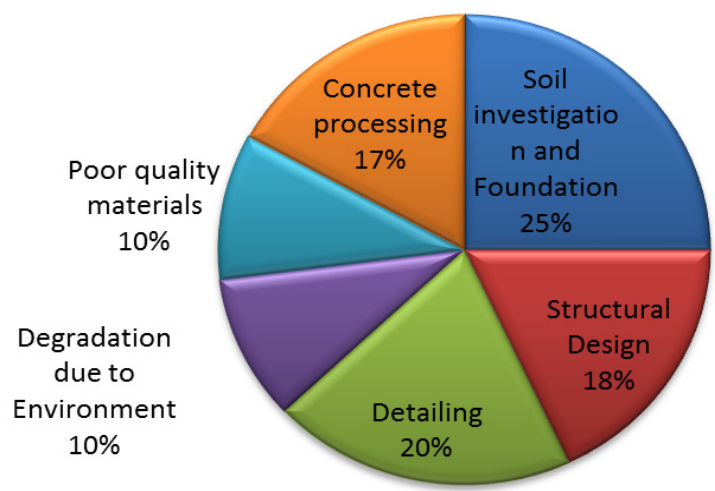

Figure 7. Causes of building collapse in the cities of Yaoundé and Douala

\section{Case Studies of Collapsing}

\subsection{Case 1 at Akwa Nord, Douala}

A four-storey building under use though under construction after ten years collapsed (see Figure 8) in Akwa Nord, Douala, on May 18, 2014.

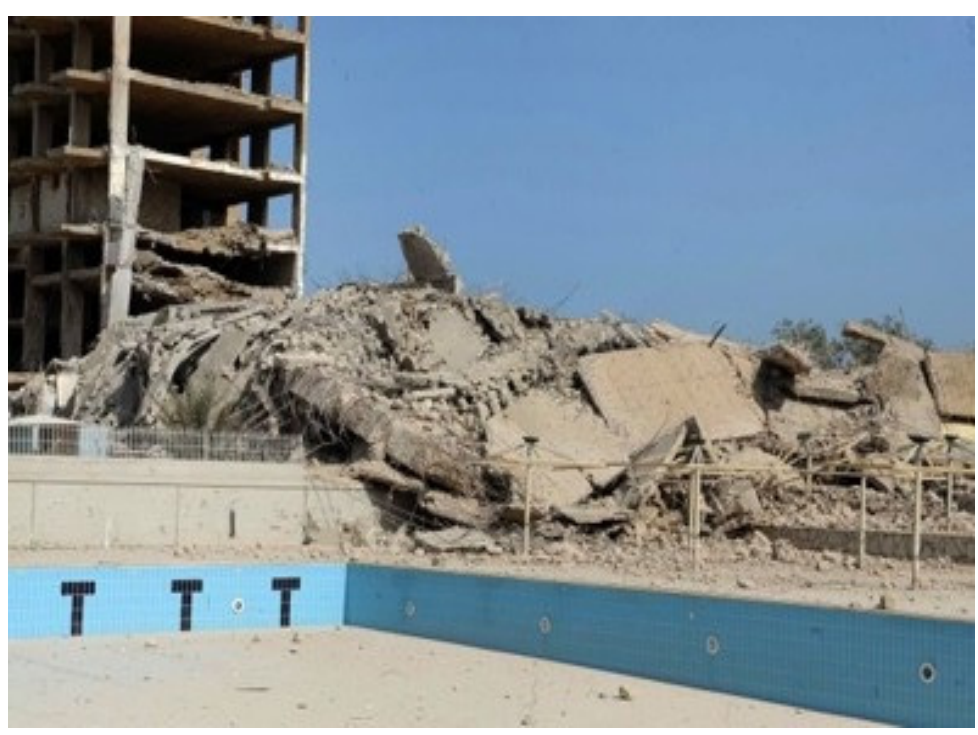

Figure 8. Collapse site of a 4-storey building at Akwa Nord, Douala (Source: Journal le messenger, 2014)

Figure 9 shows that, excessive loading, degradation due to environmental factors and structural design form major causes of the building collapse. The trio had $35 \%, 25 \%$ and $25 \%$ occurrence respectively. 


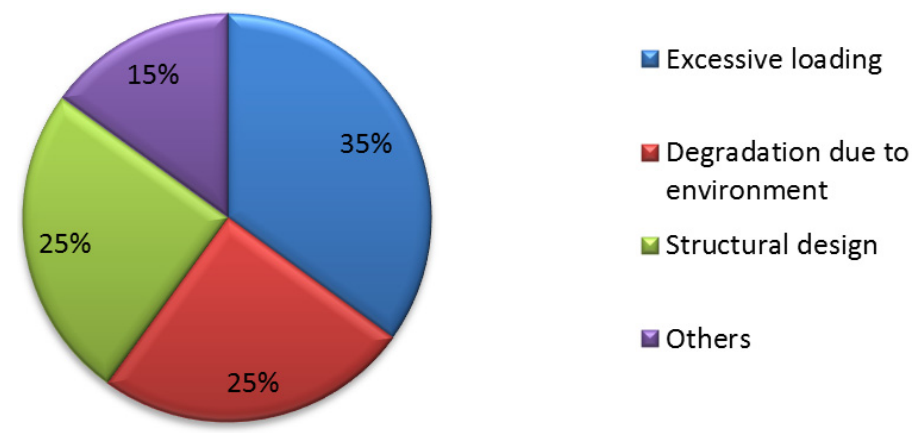

Figure 9. Causes of a 4-storey building collapse at Akwa Nord, Douala

\subsection{Case 2 at Nkolndongo, Yaoundé}

On February 26, 2010, the structure of the building in Nkolndongo, Yaoundé catastrophically collapsed (Figure $10)$, bringing down the entire five-storey reinforced concrete structure. The building was originally designed for five-storey building for residential use, but out of greediness, the owner decided to add extra one floor. This additional weight on the structure without due consideration of the foundation, column and slab led to the collapse of the building (Amadi et al., 2012; Oke, Amadi, Abalaka, \& Akerele, 2009a) as a result of structural inefficiency due to excessive loading of area after remodelling, improper binding of units and unequal distribution of load (Ayuba et al., 2012).

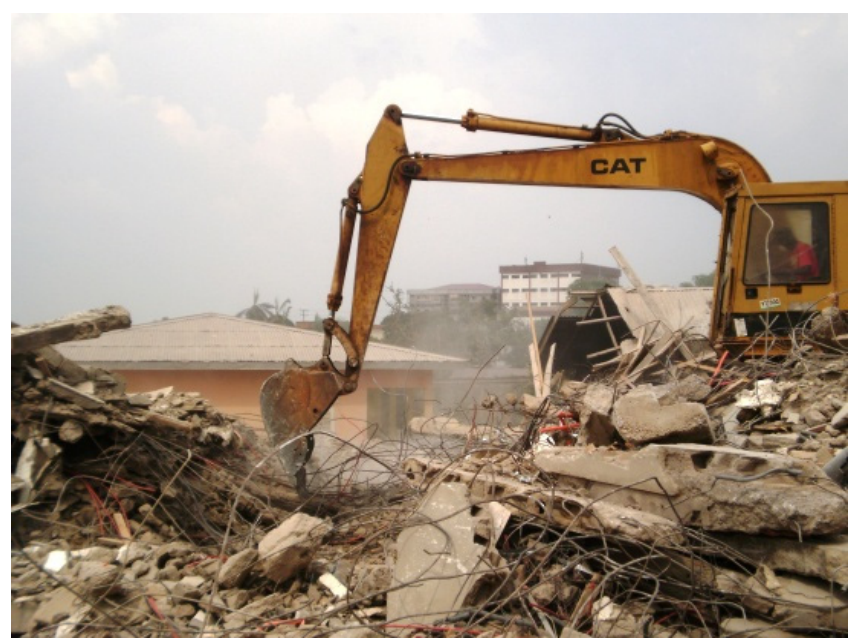

Figure 10. Collapse site of a 5-storey building at Nkoldongo, Yaoundé (Source: Journal du Cameroun, 2010)

Figure 11 shows the percentages of the most probable causes. From this figure, it can be observed that excessive loading and structural design form major causes of the building collapse with $40 \%$ and $35 \%$ occurrence respectively.

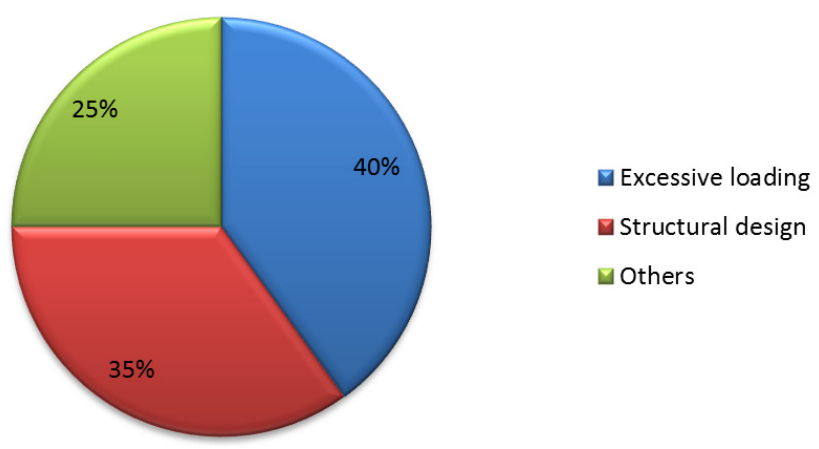

Figure 11. Causes of a 5-storey building collapse at Nkolndongo, Yaoundé 


\section{Causes of Building Collapse in Yaoundé and Douala}

Collapse according to Bosede and Sunday (2014) and Dimuna (2010), is a state of complete failure, when the structure has literally given way and most members have caved-in crumbled or buckled. Alinaitwe and Ekolu (2014) and Bosede and Sunday (2014); Ayuba et al. (2012); Fakere, Fadairo and Fakere (2012) have identified certain factors as causes of collapse of the buildings in East Africa and Nigeria respectively. Certain of them are also found as causes of buildings or structures collapse in the main cities of Cameroon (Yaoundé and Douala). Among those factors we have:

\subsection{Inadequate Preliminary Works}

Preliminary works are operations which include site investigation and foundation. Site investigation is to determine the properties of the soil strata. Building collapse is imminent where these operations are carried out shoddily (Bosede \& Sunday, 2014; Fakere et al., 2012). Seeley (1987) (as cited in Bosede \& Sunday, 2014 and Fakere et al., 2012) said that all potential building sites would need to be investigated to determine their suitability for buildings and the nature and extent of the preliminary work that would be needed. Particular attention should be given to the nature of the soil and its probable load-bearing capacities, as there may be variations over the site. Adequate site investigation prevents the issue of foundation problem because it would ensure that the most appropriate foundation is prescribed (Bosede \& Sunday, 2014; Fakere et al., 2012).

\subsection{Adoption of Wrong Foundation}

According to Lambe and Whitman (1979) (as cited in Bosede \& Sunday, 2014 and Fakere et al., 2012), foundation is a part of the structure in direct contact with the ground and which transmits the load of the structure to the ground which plays an important role in the construction of building structures. Foundation is expected to carry all the dead, super-imposed and wind loads from a building to the soil on which the building rests in such a way that settlement of the structure is limited so that failure of the underlying soil is prevented (Bosede \& Sunday, 2014; Fakere et al., 2012). The depth of soil strata in response to the loadings from the structure has to be located properly in order to safely bear the foundation of the building. Otherwise, the structure will fail (Bosede \& Sunday, 2014; Fakere et al., 2012).

\subsection{Effect of Low Quality Sand Crete Blocks on Structural Wall}

According to Ayuba et al. (2012), Sand Crete blocks are composite units made up mixture of sand, cement and water in specified proportion. The quality of Sand Crete block used in the construction of walls play a very significant role in the total strength of the wall. The quality of any sand Crete block is largely determined by it properties which include strength, durability, thermal conductivity, fire resistance, density, efflorescence and dimensional charges (Ayuba et al., 2012). However, these properties greatly depend on the type and proportioning of the constituent materials, mix ratio, mode of compaction and duration of curing (Ayuba et al., 2012). These constituent materials are first mixed and then compacted in moulds to form pre-cast units. On setting and hardening, the blocks attain sufficient strength and can be used as walling units. The quality of block used in Yaoundé and Douala is a factor in building failure. A lot of these blocks even break in the process of conveying them to the site. Most blocks do not meet the standard requirements.

\subsection{Poor Concrete Mix Ratio}

Neville and Brooks (2010), defined concrete as any product or mass made by the use of a cementing medium, and this medium is the product of reaction between hydraulic cement and water. It can also be considered no more than a mixture of cement, water, aggregate (fine and coarse) and admixture (Neville \& Brooks, 2010). In providing support for a building, concrete is the most common constuction material used in Cameroon. Tomilson (1980) (as cited in Bosede \& Sunday, 2014 and Fakere et al., 2012) reiterated that poor materials do not make good concrete. The cement, sand and stone must all be sound and have the types and qualities specified. The result of poor concrete works is building collapse (Bosede \& Sunday, 2014; Fakere et al., 2012).

\subsection{Neglect of Design and Building Approval Procedures}

Building construction is typically regulated by the city or town council authorities. It is a normal procedure that before a permanent building construction is commenced on a site within the city, its architectural and structural drawings, and bill of quantities are submitted to the local authorities for approval by a professional engineer (Alinaitwe \& Ekolu, 2014). Normally, such documents will have been prepared by a professional architect and/or engineer. Construction works that are conducted without undertaking this approval process would normally be deemed illegal.

In developing countries, two challenges arise from implementing these legal procedures. Firstly, the municipal or 
town authorities may not have sufficient capacity of professionally qualified engineers needed to approve sophisticated structural designs. This alludes to the shortage of scarce skills generally. Another issue is associated with neglect of procedures, whereby the required approval process may be circumvented by a proprietor through influence peddling or other means. A well-meaning proprietor would appreciate the importance of proper checking of designs, however, financial pressures which come with the need to cut down costs often lead to flawed decisions such as neglecting design approval procedures since it involves engaging professional services of architects and engineers. This, however, may be considered to be a warning sign of embedded flaws that may result in potential failure problems at the construction stage (Alinaitwe \& Ekolu, 2014).

In the Nkolndongo building case, the investigation found that the design approval process was simply not undertaken. Moreover for a 5-storey reinforced concrete building, there were no structural drawings and no bills of quantities prepared. These strong signs of non-conformity with approval procedures would have been reason enough for the municipal authorities to query the construction at its early stages and interrogate their lack of approved documents. Interestingly, the municipal authorities did not undertake any such action to inspect and monitor the site construction, and by so doing the authorities too passively contributed to the tragic collapse (Alinaitwe \& Ekolu, 2014).

\subsection{The role of Professional and Other Participants in the Building Industry}

All the participants involved in the construction of buildings are contributors to building failures in one way or the other (Ayuba et al., 2012). Onyemachi and Uji (2005) (as cited in Ayuba et al., 2012) observed that architects contribute to building collapse by not involving engineers at all stages of construction. Today, Architects are seen undertaking buildings all alone without the consultation of Engineers (Ayuba et al., 2012). Clients are also involved on cutting corners, monetary delays and involvement of non-competent professionals and building without building plans (Ayuba et al., 2012).

In addition, other factors identified include:

- Poor materials and workmanship

- Lack of equipment in the construction industry

- Absence of professional supervision of site works

- Inadequate design

- Faulty construction methodology

- Illegal conversion of building

- Change of use of buildings

- Financial pressures

- The use of quacks or of non-professionals in building construction

- Lack of quality control check

- Fire disaster

- Poor management and maintenance in buildings

- Reinforcement steel corrosion

- Erosion (Figure 12)

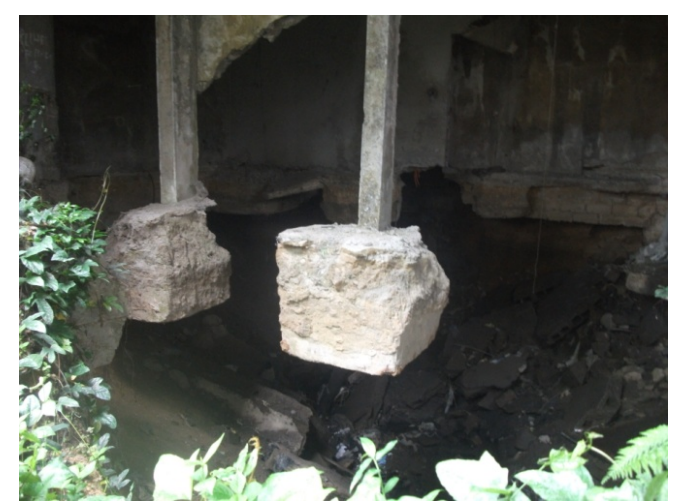

Figure 12. Foundation failure due to Erosion (Source: Author, 2014)

\section{Recommendations}

Based on the analysis of the findings of investigations conducted on collapsed buildings (structures) in Yaoundé and Douala, the following recommendations were drawn: 
1. A preliminary geotechnical investigation should be carried out before design. Prohibiting the use of quacks or of non-professionals in building construction.

2. The Cameroonian National Order of Civil Engineers (ONIGC), National Order of Architects (ONAC), National Order of Urbanists and Geoscientists, should ensure that only registered and qualified professionals are involved from design stage to completion stage in the construction of future buildings.

3. Professional bodies should hold regular workshops and Continuous Professional Development Programmes (CPDP) for their members to keep them abreast of current developments in their chosen profession.

4. Construction materials quality control check should be made before commencement of using.

5. Getting approval before commencing construction on site.

6. Inspection of construction site should be enforced at the local government authorities and relevant government departments to ensure compliance with approved building plans.

\section{Conclusion}

The purpose of this study was to elaborate various cases of building structures collapsed that occurred in Yaoundé and Douala, Cameroon between 2010 and 2014 and to investigate the factors causing such incidents. The study concluded that, the causes of buildings collapse in Yaoundé and Douala from 2010 to 2014 were absence of soil investigation and foundation, structural design, detailing, degradation due to environmental factors, use of poor quality materials and concrete processing.

In the two case studies considered, the study revealed that the major causes of building failures were excessive loading, structural design, degradation due to environmental factors and other causes.

\section{Acknowledgements}

This article is a part of research works at ENSET- University of Douala. The participation and the contribution of the students are particularly thanked. The authors would like to thank their colleagues of the Department of Civil Engineering and Nwaha Sahba Hans Salomon, a final year Civil Engineering student for his collaboration and availability.

\section{References}

Alinaitwe, H. M., \& Ekolu, S .O. (2014). Failure of Structures in East Africa with focus on the causes of failures in the construction phase. In S. O. Ekolu et al. (Eds.), Proceedings of the First International Conference on Construction Materials and Structures, 24-26 November, Johannesburg, South Africa, 76-85.

Amadi, A. N., Eze, C. J., Igwe, C. O., Okumlola, I. A., \& Okoye, N. O. (2012). Architect's and Geologist's View on the Causes of Building Failures in Nigeria. Modern Applied Science, 6(6), 31-38. http://dx.doi.org/10.5539/mas.v6n6p31.

Ayuba, P., Olagunju, R. E., \& Akande, O. K. (2012). Failure and Collapse of Buildings in Nigeria: The role of professionals and other participants in the building industry. Inter-disciplinary Journal of Contemporary Research in business, 4(6), 1267-1272.

Bosede, A. F., \& Sunday, G. M. (2014). An Investigation on the Causes of Building Collapse in Nigeria. Journal of Environmental Sciences and Resources Management, 6(1), 12-22.

Dimuna, K. O. (2010). Incessant Incidents of Building Collapse in Nigeria: A challenge to Stakeholders. Global Journal of Research in Engineering, 10(4), 75-84.

Fakere, A. A., Fadairo, G., \& Fakere, R. A. (2012). Assessment of building collapse in Nigeria: A Case of Naval Building, Abuja, Nigeria. International Journal of Engineering and Technology, 2(4), 584-591.

Journal du Cameroun. (2010). Effondrement des Immeubles. Retrieved from http://www.camerounactu.net/fr/societe/faits-divers/852-effondrement-dun-immeuble-a-yaounde-le-bilan-sa lourdit.

Journal le Messenger. (2013). Effondrement des Immeubles. Retrieved from http://www.journalducameroun.com/article.php?aid=15630.

Journal le Messenger. (2014). Effondrement des Immeubles. Retrieved from http://www.journalducameroun.com/article.php?aid=15630.

Neville, A. M., \& Brooks, J. J. (2010). Concrete Technology (2nd ed.). Longman Group, UK publishers Ltd.

Oke, S. A., Amadi, A. N., Abalaka, A. E., \& Akerele, R. T. (2009a). Result of subsoil investigation on a collapsed 
building site in Lagos. Nigerian Journal of Construction Technology and Management, 10(1\&2), 36-45.

Oseghale, G. E., Ikpo, I. J., \& Ajayi, O. D. (2015). Causes and Effects of building collapse in Lagos State, Nigeria. Civil and Environmental Research, 7(4), 34-43.

Tauheed, I. A. (2007). Curbing the Collapse of buildings in Nigeria: $1^{\text {st }}$ Annual National Conference, School of Environmental Technology FUT Minna, $28^{\text {th }}-2^{\text {nd }}$ March, pp37-39.

\section{Copyrights}

Copyright for this article is retained by the author(s), with first publication rights granted to the journal.

This is an open-access article distributed under the terms and conditions of the Creative Commons Attribution license (http://creativecommons.org/licenses/by/3.0/). 